\title{
Article \\ Whole Body Ip6k1 Deletion Protects Mice from Age-Induced Weight Gain, Insulin Resistance and Metabolic Dysfunction
}

\author{
Sarbani Ghoshal ${ }^{1,2, *,+} \mathbb{D}_{\text {, }}$ Sandip Mukherjee ${ }^{3,+}{ }^{,}$Molee Chakraborty ${ }^{3}$, Eliwaza Naomi Msengi ${ }^{3}$, Jake Haubner ${ }^{3}$ \\ and Anutosh Chakraborty ${ }^{1,3, *}$
}

1 Department of Metabolism and Aging, The Scripps Research Institute, Jupiter, FL 33458, USA

2 Department of Biological Sciences and Geology, QCC-City University of New York, New York, NY 11364, USA

3 Department of Pharmacology and Physiology, Saint Louis University School of Medicine, Saint Louis, MO 63104, USA; sandip.mukherjee@health.slu.edu (S.M.); molee.chakraborty@health.slu.edu (M.C.); eliwazanao.msengi@slu.edu (E.N.M.); jake.haubner@slu.edu (J.H.)

* Correspondence: sghoshal@qcc.cuny.edu (S.G.); anutosh.chakraborty@health.slu.edu (A.C.)

+ These authors contributed equally to this work.

check for updates

Citation: Ghoshal, S.; Mukherjee, S.; Chakraborty, M.; Msengi, E.N.; Haubner, J.; Chakraborty, A. Whole Body Ip $6 k 1$ Deletion Protects Mice from Age-Induced Weight Gain, Insulin Resistance and Metabolic Dysfunction. Int. J. Mol. Sci. 2022, 23, 2059. https://doi.org/10.3390/ ijms23042059

Academic Editor: Sangwon F. Kim

Received: 15 December 2021

Accepted: 10 February 2022

Published: 12 February 2022

Publisher's Note: MDPI stays neutral with regard to jurisdictional claims in published maps and institutional affiliations.

Copyright: (C) 2022 by the authors. Licensee MDPI, Basel, Switzerland. This article is an open access article distributed under the terms and conditions of the Creative Commons Attribution (CC BY) license (https:// creativecommons.org/licenses/by/ $4.0 /)$.

\begin{abstract}
Background: We previously demonstrated that disruption of IP6K1 improves metabolism, protecting mice from high-fat diet-induced obesity, insulin resistance, and non-alcoholic fatty liver disease and steatohepatitis. Age-induced metabolic dysfunction is a major risk factor for metabolic diseases. The involvement of IP6K1 in this process is unknown. (2) Methods: Here, we compared body and fat mass, insulin sensitivity, energy expenditure and serum-, adipose tissue- and livermetabolic parameters of chow-fed, aged, wild type ( $a W T)$ and whole body Ip $6 k 1$ knockout $(a K O)$ mice. (3) Results: IP6K1 was upregulated in the adipose tissue and liver of $a W T$ mice compared to young WT mice. Moreover, Ip $6 k 1$ deletion blocked age-induced increase in body- and fat-weight and insulin resistance in mice. aKO mice oxidized carbohydrates more efficiently. The knockouts displayed reduced levels of serum insulin, triglycerides, and non-esterified fatty acids. Ip6k1 deletion partly protected age-induced decline of the thermogenic uncoupling protein UCP1 in inguinal white adipose tissue. Targets inhibited by IP6K1 activity such as the insulin sensitivity- and energy expenditure-inducing protein kinases, protein kinase $\mathrm{B}(\mathrm{PKB} / \mathrm{Akt})$ and $\mathrm{AMP}$-activated protein kinase (AMPK), were activated in the adipose tissue and liver of $a K O$ mice. (4) Conclusions: Ip6k1 deletion maintains healthy metabolism in aging and thus, targeting this kinase may delay the development of age-induced metabolic dysfunction.
\end{abstract}

Keywords: IP6K1; aging; metabolism; adipose tissue browning; weight gain; insulin resistance

\section{Introduction}

The increased prevalence of obesity is a major health concern. Aging significantly increase the risks of obesity and obesity-induced co-morbidities such as type-2 diabetes mellitus (T2DM), non-alcoholic fatty liver disease/steatohepatitis (NAFLD/NASH), cardiovascular disease and certain types of cancer [1-4]. Excess fat accumulation exacerbates frailty in older persons. Conversely, metabolic dysfunction accelerates aging, as young people with obesity and T2DM often exhibit features of accelerated aging [5].

Aging impairs functions of metabolic tissues such as adipose tissue, liver, and skeletal muscle [5-7]. In young and healthy conditions, the white adipose tissue (WAT) stores excess energy as triglycerides (TAG). Conversely, the mitochondria-enriched adipocytes in the brown adipose tissue (BAT) and brown-like "beige" or "brite" adipocytes in certain WAT depots (for example, the inguinal depot or IWAT) express mitochondrial uncoupling protein 1 (UCP1) to expend energy by thermogenesis. This process facilitates fat loss and improves insulin sensitivity in rodents and humans [8-12]. Moreover, adipose tissue is a major endocrine organ, secreting numerous adipokines that regulate energy 
metabolism, inflammation, and various other processes in the body [13]. Chronic energy accumulation in obesity and/or aging disrupts energy homeostasis, alters adipokine secretion and immune response, causing adipose tissue dysfunction [14,15]. Dysfunctional adipocytes release inflammatory cytokines that reduce their fat-storing ability and increase the levels of non-esterified fatty acid (NEFA), which causes insulin resistance and lipotoxic liver injury [16,17]. Age-induced depletion of brown/beige adipocytes and subsequent loss of UCP1 have been shown to aggravate metabolic pathologies in rodents and humans [5,18-20]. Moreover, obesity- and/or aging-induced hyperinsulinemia causes pathway-selective insulin resistance in the liver, reducing glucose uptake and increasing gluconeogenesis and de novo lipogenesis, which subsequently leads to hyperglycemia and lipotoxic liver injury $[6,16,17,21,22]$.

The characterization of novel proteins and/or pathways involved in metabolism and aging is crucial to understand the mechanisms that regulate these processes, and to develop therapeutic strategies to improve healthspan $[6,23]$. The use of new mouse models that lack or overexpress a novel gene of interest is particularly useful in this regard. Using various knockout mouse models, we previously discovered the inositol pyrophosphate (5-IP7) biosynthetic enzyme inositol hexakisphosphate kinase 1 (IP6K1) as a novel target in high-fat diet-induced obesity. A family of three IP6Ks synthesizes the biomolecule 5-IP7 in mammals by phosphorylating inositol hexakisphosphate (IP6) [24-28]. IP6K1 regulates metabolic functions of adipose tissue, liver and pancreatic $\beta$ cells, whereas IP6K3 modulates metabolism of the skeletal muscle [26,29-32]. IP6K1 impairs insulin signaling by inhibiting the insulin effector protein kinase Akt, promoting high-fat diet-induced insulin resistance [33]. Moreover, IP6K1 reduces whole-body energy expenditure by inhibiting adipose tissue browning and thermogenesis [34]. IP6K1 diminishes energy expenditure and stimulates fatty acid biosynthesis by inhibiting the metabolism enhancing AMP-activated protein kinase (AMPK) [34,35]. IP6K1 also reduces serum levels of the insulin-sensitizing and metabolically favorable adipokine, adiponectin [34,35]. Consequently, high-fat diet-fed, whole-body- or adipocyte-specific Ip6k1-KO mice are protected from obesity, hyperinsulinemia, insulin resistance, and hepatic steatosis [33-35]. Moreover, whole-body- or hepatocyte-specific Ip6k1 deletion protects mice from high-fat and high-cholesterol (Western) diet-induced lipotoxic liver injury and NAFLD/NASH [36]. IP6K1 also promotes insulin secretion from pancreatic $\beta$ cells $[31,32,37]$. Accordingly, I $6 k 1$ deletion diminishes insulin secretion whereas transgenic mice that express a hyperactive IP6K1 display augmented insulin release, congenital hyperinsulinemia, and obesity [32]. In summary, IP6K1 regulates metabolism via pleiotropic mechanisms.

High-fat diet-induced obesity in rodents does not exactly mimic human obesity. A major reason is that such high percentages of fat (40-60\% kcals from fat) are not regularly consumed by humans. Conversely, aged mice develop metabolic dysfunction despite consuming a normal chow diet $(\sim 62 \%, \sim 25 \%$ and $\sim 13 \% \mathrm{kcals}$, from carbohydrate, protein, and fat, respectively). Mechanistically, high-fat diet-induced obesity is caused due to rapid accumulation of fat, whereas aging-induced weight gain occurs because of fat synthesis from carbohydrates over time. Thus, determining the impact of a protein on both models of metabolic dysfunction is necessary. However, no studies have yet been done to define IP6K1's role in aging-induced metabolic dysfunction. To address this, here we compared metabolic features of chow-fed, aged (22-months), WT and Ip6k1-KO ( $a W T$ and $a K O$ ) mice. Female subjects are often overlooked in research, including metabolic research, despite the sex-specific differences in phenotypes [38-41]. Therefore, in this study, we used mice of both sexes.

\section{Results}

2.1. Body Weight and Composition

Whole-Body Deletion of Ip6k1 Protected Mice from Age-Induced Weight and Fat Gain

We determined whether aging differentially regulated body weight and composition in WT and $K O$ male and female mice. Young, chow-fed $K O$ male mice displayed a slight, 
albeit significant reduction in body weight (Figure 1A), which conforms with previous reports [33,37]. Interestingly, with age, WT males gained substantially more body weight than $\mathrm{KO}$ males (Figure 1A,B). Body composition analysis revealed that total fat mass was considerably lower in 12- and 22-month-old $a K O$, compared to aWT males (Figure 1C). Total lean and fluid mass were also reduced in $a K O$ males, although to a lesser extent than fat mass (Figure 1C). The percent fat mass (normalized to total body weight) was also significantly reduced in 12- and 22-month-old $a K O$ male mice (Figure 1D). Percent lean mass increased in 12-month-old aKO and was similar in 22-month-old $a W T$ and $a K O$ male mice (Figure 1D). Percent fluid mass was similar in both genotypes.

A

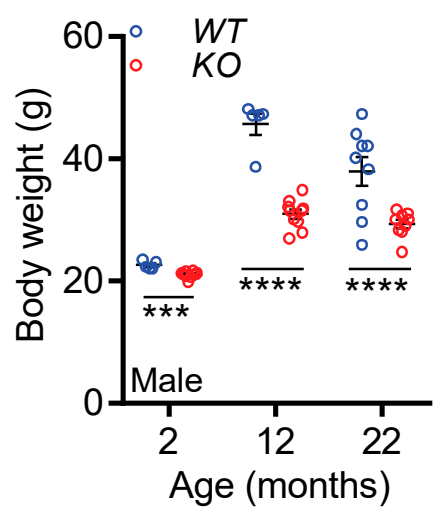

D

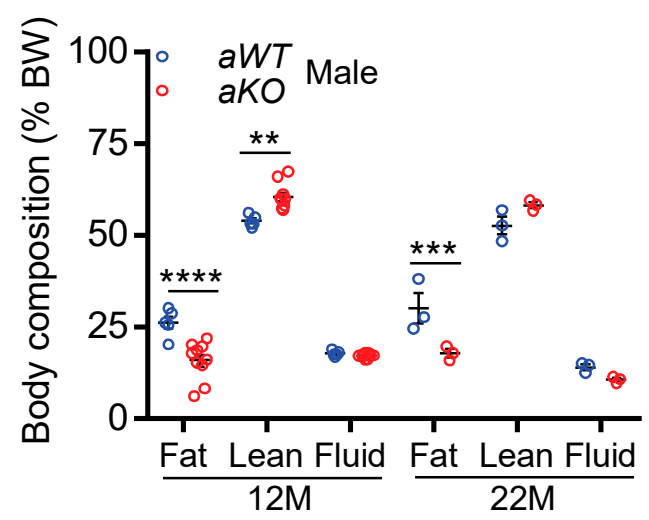

B

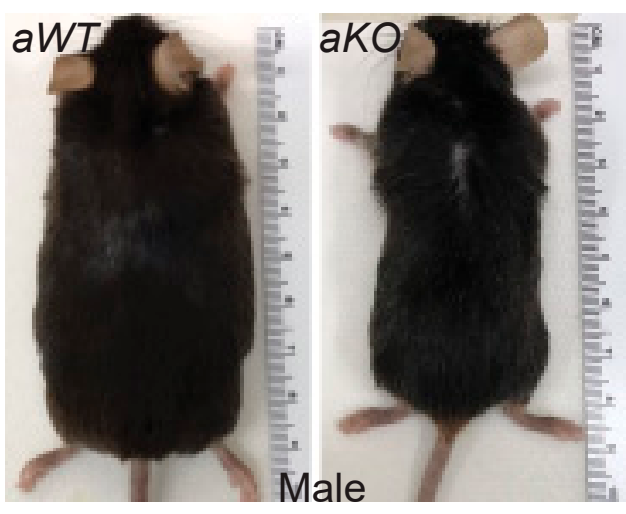

E

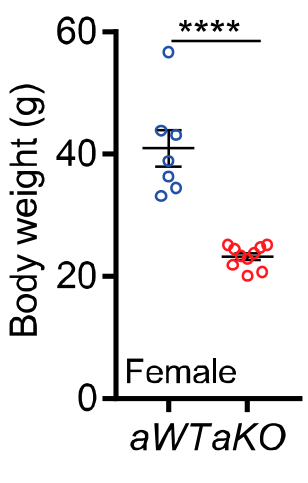

C

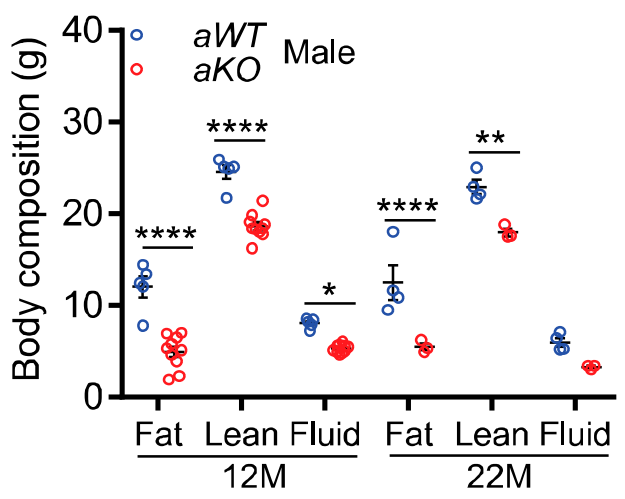

F

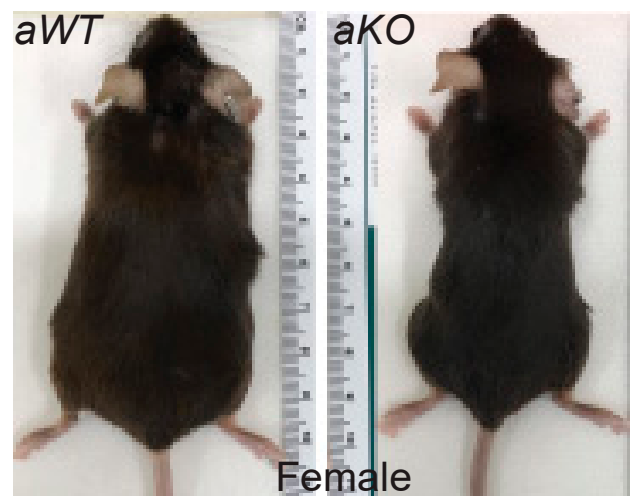

Figure 1. Whole-body deletion of Ip $6 k 1$ protected mice from age-induced weight and fat gain. Wholebody deletion of $I p 6 k 1$ protected mice from age-induced weight and fat gain. (A,B). Ip $6 k 1$ deleted $(\mathrm{KO})$ male mice were substantially protected from age-induced increase in body weight. $n=5$ and 10 for 2- and 12-month-old WT and KO; and 9 each for 22-month-old mice). (C). Total body fat, lean and fluid mass were significantly reduced in $a K O$ male mice. (D) Percent fat mass (normalized to total body weight) was substantially less in $a K O$ male mice. Percent lean mass was higher in 12M-old $a K O$, whereas its was similar in 22M-old $a K O$ and $a W T$ male mice. Percent fluid mass was similar in both genotypes. $n=5$ and 10 for 12-month-old $W T$ and KO; and 3 each for 22-month-old male mice. (E,F) $a K O$ (22-month-old) female mice were protected from age-induced increase in body weight. $n=7$ and 10 for $a W T$ and $a K O$ female mice. Number of mice $(n)$ used in each experiment are presented as individual datapoints. Mean \pm s.e.m. values are shown within dot plots. For 2 independent data sets, two-tailed unpaired Student's $t$-test was used. ${ }^{*} p<0.05,{ }^{* *} p<0.01,{ }^{* * *} p<0.001,{ }^{* * * *} p<0.0001$.

Aged (22-month-old) female $a K O$ mice displayed an even greater difference in body weight, compared to aWT mice (Figure 1E,F). Like males, both total and percent fat mass were substantially lower in female $a K O$ mice (Figure S1A,B). Total lean mass decreased but percent lean mass increased in female $a \mathrm{KO}$ mice (Figure S1A,B). Fluid mass was marginally 
reduced in $a K O$ females. Thus, $a K O$ mice displayed an overall reduction in body size. However, when normalized to body weight, Ip $6 k 1$ deletion specifically blocked aginginduced accumulation of fat without significantly altering lean or fluid mass.

\subsection{Serum Metabolic Profiles}

aKO Mice Displayed Improved Serum Metabolic Profiles

Next, we checked whether the lean phenotype delayed age-induced metabolic aberration in $a K O$ male and female mice. $a W T$ and $a K O$ male mice displayed average serum insulin levels of 2.9 and $0.74 \mathrm{ng} / \mathrm{mL}$, respectively (Figure 2A). These values were 1.2 and $0.4 \mathrm{ng} / \mathrm{mL}$ in young $W T$ and $K O$ mice [37]. Thus, $a K O$ mice maintained normal levels of serum insulin. Moreover, ad libitum blood glucose levels were higher in $a W T$ but not in $a K O$ mice (Figure S2A) (normal value $120 \mathrm{mg} / \mathrm{dL}$ ). Next, we tested the efficiency of glucose disposal in $a W T$ and $a K O$ male mice in a glucose tolerance test (GTT). Although fasting $(16 \mathrm{~h})$ blood glucose levels are similar in young $W T$ and $K O$ mice $(\sim 70 \mathrm{mg} / \mathrm{dL})$ [37], aging-induced increase in fasting blood glucose levels was less in $a K O$ mice (average values were 126 and $150 \mathrm{mg} / \mathrm{dL}$ in $a K O$ and $a W T$ mice, respectively; 0 time point of GTT; $p=0.0544$; Figure 2B). Moreover, $a K O$ male mice disposed of blood glucose more efficiently than $a W T$ in a glucose tolerance test (GTT) (Figure 2B,C). Both young WT and KO male mice efficiently disposed of blood glucose following exogenous insulin injection (insulin tolerance test-ITT) [37]. However, aKO but not $a W T$ male mice showed improved glucose disposal in an ITT (Figure 2D,E).

Ad libitum blood glucose levels were similar in $a W T$ and $a K O$ female mice (data not shown). Yet, female $a K O$ mice showed reduced serum insulin and improved glycemic profiles in a GTT (Figure 2F-H). Exogenous insulin injection reduced blood glucose in both female genotypes, albeit slightly more efficiently in $a K O$ mice (Figure 2I,J). Different glycemic profiles in aWT male and female mice in ITT indicated that aged males were more insulin resistant than female mice, which is a commonly observed phenomenon in mice [42].

Aging did not increase serum TAG levels in WT (compared to reported values in young WT [43]). These values were lower in $a K O$, compared to $a W T$ mice (Figure $2 \mathrm{~K}, \mathrm{~L}$ ). Serum NEFA levels were higher in aged mice of both genotypes, compared to young mice [43]. However, the increase was less pronounced in $a K O$ mice, and thus $a K O s$ displayed reduced serum NEFA levels than aWT mice (Figure 2M,N). Serum cholesterol and phospholipid levels were largely similar (Figure S2B-E). These results suggest improved serum metabolic profiles in $a K O$ mice.

\subsection{Energy Expenditure, Food Intake and Activity}

\section{aKO Mice Expended Carbohydrates More Efficiently Than aWT Mice}

Like chow- and high-fat-fed young mice [35], aWT and $a K O$ mice consumed similar amounts of food (Figure S3A,B). When normalized to body weight, $a K O$ mice exhibited a slight but significant increase in food intake (Figure S3C,D). Slight increase in food intake was presumably necessary to compensate for the negative energy balance in the $a K O$ mice. Total and ambulatory activity profiles were largely similar in both genotypes (Figure S3E,F). Whole body energy expenditure studies showed that the volume of oxygen consumption $\left(\mathrm{VO}_{2}\right)$ was similar in both aged genotypes (Figure 3A). Accordingly, energy expenditure (EE) was also similar in $a W T$ and $a K O$ mice (Figure $3 \mathrm{~B}$ ). However, the nighttime respiratory exchange ratio (RER) was significantly higher in the $a K O$ mice (Figure $3 \mathrm{C}$ ). Thus, $a K O$ expended more carbohydrate and less fat than aWT mice during nighttime (Figure 3D,E). The major source of energy in the chow-diet is carbohydrate. Thus, age-induced weight gain in mice is largely due to increased lipogenesis rather than augmented accumulation of exogenous fat, which is observed in high-fat diet-induced obesity. Efficient carbohydrate oxidation reduced fat synthesis and accumulation, leading to leanness, and metabolic improvements in chow-fed $a K O$ mice. 
A

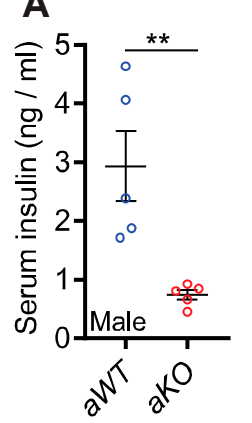

$F$

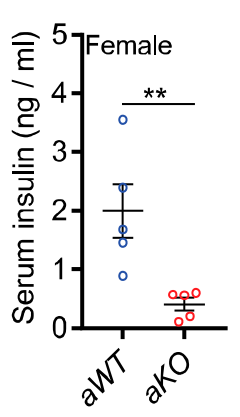

K

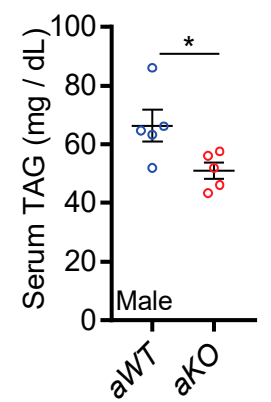

B

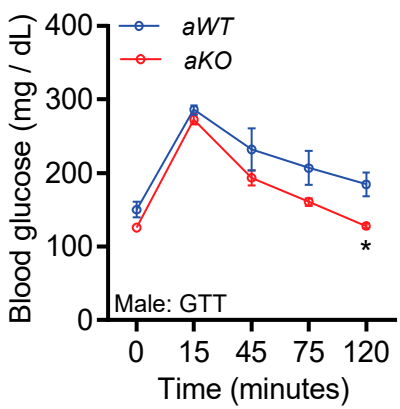

G

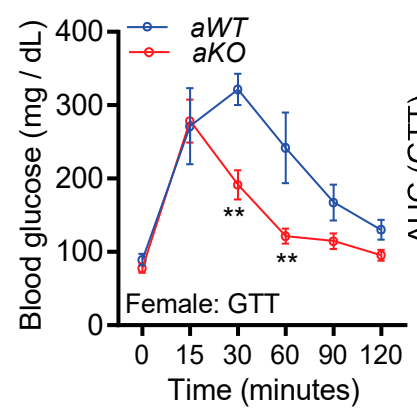

L

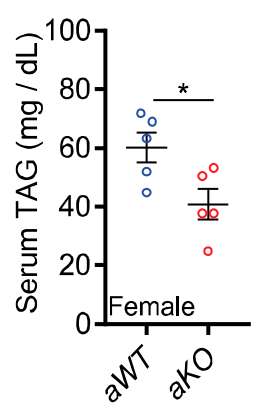

H
D
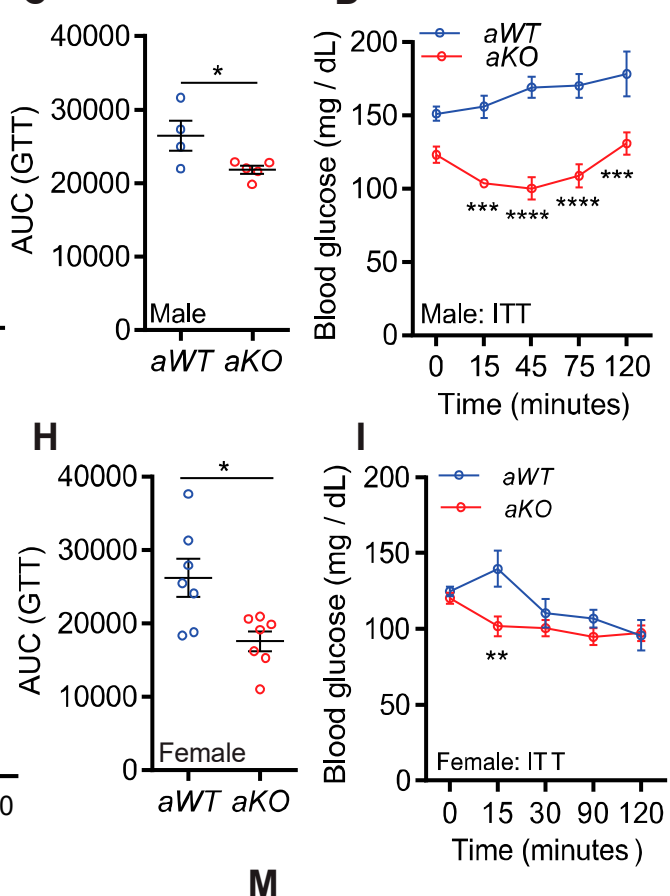

M

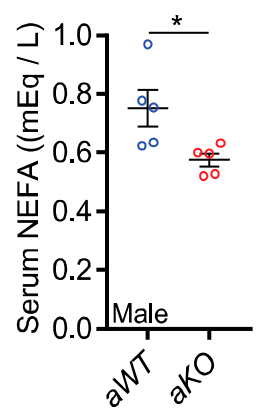

E

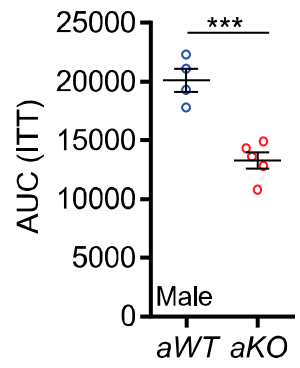

J

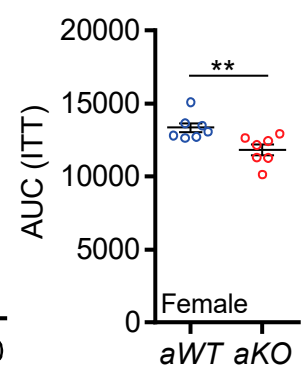

N

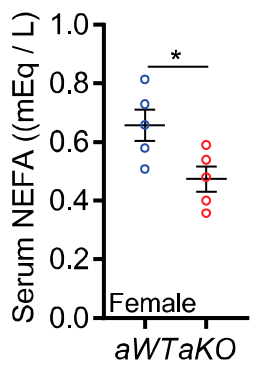

Figure 2. aKO mice displayed improved serum metabolic profiles. (A) $a K O$ male mice were protected from aging-induced hyperinsulinemia. $n=5$ mice per group. (B,C) Male $a K O$ mice disposed blood glucose more efficiently than $a W T$ mice following exogenous glucose injection (glucose tolerance testGTT). The assay was performed in 15-month-old mice. $n=4$ and 5 for $a W T$ and $a K O$ mice, respectively. $(\mathrm{D}, \mathrm{E})$ aKO but not $a W T$ male mice efficiently disposed blood glucose following exogenous insulin injection (insulin tolerance test-ITT). The assay was performed in 16-month-old mice. $n=4$ and 5 for $a W T$ and $a K O$ mice, respectively. (F) Female $a K O$ mice were protected from hyperinsulinemia. $n=5$ mice each group. $(\mathbf{G}, \mathbf{H})$ Female $a K O$ mice displayed substantially improved glycemic profiles in a GTT. The assay was performed in 15-month-old mice. $n=7$ mice per group. (I,J) Female $a K O$ mice showed slightly improved glucose disposal in an ITT. The assay was performed in 16-month-old mice. $n=7$ mice per group. $(\mathbf{K}, \mathbf{L})$ Serum TAG levels were reduced in $a K O$ male and female mice compared to $a W T$ littermates. $n=5$ mice each group. $(\mathbf{M}, \mathbf{N})$ Both sexes of $a K O$ mice displayed reduced serum NEFA levels. $n=5$ mice each group. Number of mice $(n)$ used in each experiment are presented as individual datapoints. Mean \pm s.e.m. is shown within dot plots. For multiple comparisons, two-way ANOVA with Holm-Šidák multiple comparison test and for 2 independent data sets, two-tailed unpaired Student's t-test were used. ${ }^{*} p<0.05,{ }^{* *} p<0.01,{ }^{* * *} p<0.001,{ }^{* * * *} p<0.0001$. 

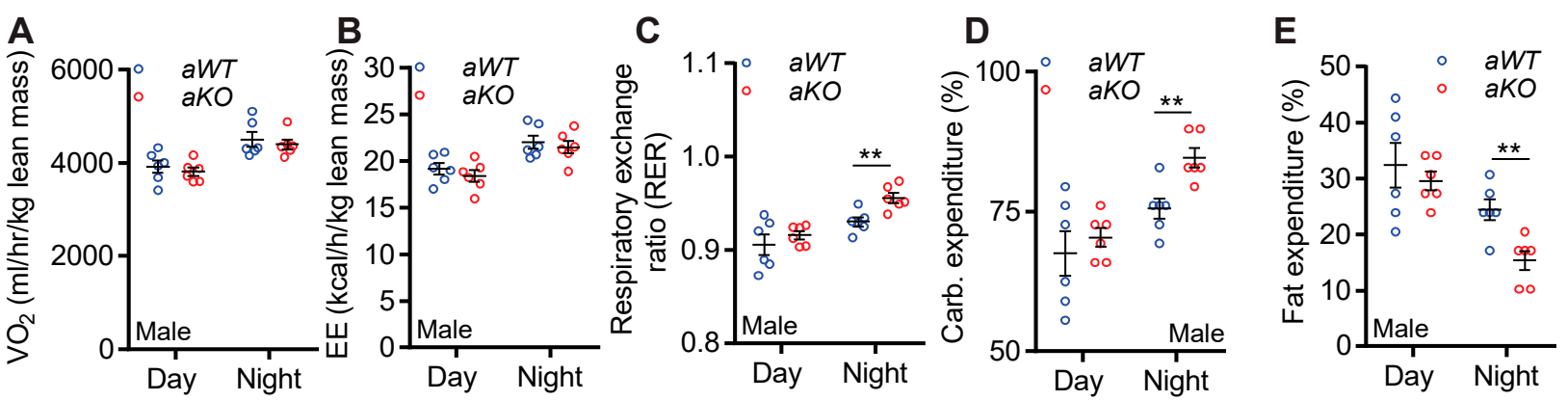

Figure 3. $a K O$ mice expended carbohydrates more efficiently than $a W T$ mice. (A) $a W T$ and $a K O$ mice consumed oxygen (VO2) to a similar extent. (B) Average energy expenditure (EE) was similar in $a W T$ and $a K O$ mice. (C) The average nighttime RER value was significantly higher in $a K O$ mice. (D) $a K O$ mice efficiently expended carbohydrate during nighttime. (E) During nighttime, aKO mice oxidized less fat than $a W T$ mice. $n=6$ mice each group. Number of mice $(n)$ used in each experiment are presented as individual datapoints. Mean \pm s.e.m. values are shown within dot plots. For 2 independent data sets, two-tailed unpaired Student's $t$-test was used. ${ }^{* *} p<0.01$.

\subsection{Metabolic Parameters of Adipose Tissue and Liver}

Age-Induced Metabolic Aberration in Adipose Tissue and Liver Was Ameliorated in Ip6k1 Deleted Mice

In high-fat diet-fed mice, IP6K1 promotes obesity and insulin resistance by reducing insulin signaling and thermogenic energy metabolism in adipose tissue and liver [33,34,36]. Here, we checked whether these parameters were improved in $a K O$ mice. aKO mice accumulated substantially less fat in epididymal (gonadal in females) and inguinal adipose tissue depots (EWAT/GWAT and IWAT) (Figures 4A and S4A, GWAT indicated by arrows, Figures 4B and S4B). UCP1, which is known to be downregulated in aging [5,18-20], was reduced in the IWAT of $a W T$, compared to young WT mice (Figures $4 \mathrm{C}$ and S4C). Interestingly, UCP1 expression was higher in the IWAT of $a K O$ compared to $a W T$, indicating that the browning property was partly maintained in the aged IWAT following Ip6k1 deletion (Figure 4D). UCP1 levels in the BAT was similar in $a W T$ and $a K O$ mice (data not shown), which is explainable as IP6K1 regulates browning of WAT without altering BAT functions [34]. Like adipose tissue, liver weight was also reduced in male and female aKO mice (Figures 4E and S4D). Microsteatosis developed to a much higher extent in $a W T$ compared to $a K O$ mice (Figures $4 \mathrm{~F}$ and S4E, indicated by arrows). Accordingly, aKO mice accumulated less TAG in the liver (Figure 4G). IP6K1 diminishes insulin signaling and energy expenditure by inhibiting the protein kinases Akt and AMPK [33-35]. Accordingly, stimulatory phosphorylation levels of Akt (S473) and AMPK (T172) increased in the adipose tissue and liver of $a \mathrm{KO}$ mice (Figures $4 \mathrm{H}$,I and S4F-I).

Histology of EWAT showed reduced adipocyte size in aKO mice (Figure 4J). Obesity- or aging-induced adipocyte dysfunction triggers infiltration of inflammatory M1 macrophages and reduces the population of insulin-sensitizing M2 macrophages [44-48]. Infiltrated macrophages form the crown-like structures in the adipose tissue, which was present in $a W T$ but not in $a K O$ mice (Figure $4 \mathrm{~J}$, indicated by arrows). Moreover, markers of M1 macrophages such as Cd11c, Tnf $\alpha, I L 1 \beta$ and $C x c l 2$ were downregulated whereas the M2 marker Cd163 was upregulated in the EWAT of $a K O$ mice (Figure $4 \mathrm{~K}$ ). Other inflammatory markers IL6, IL1 $\alpha$ and CXCl1 and the M2 marker Arg1 were similarly but insignificantly altered. Expression levels of $F 4 / 80$ were unaltered, indicating that the total population of macrophages was similar in the EWAT of $a W T$ and $a K O$ mice (Figure $4 \mathrm{~K}$ ). Like EWAT, markers of the M1 and M2 macrophages were altered in the liver of $a K O$ mice (Figure $4 \mathrm{~L}$ ). Aging did not substantially increase serum levels of the hepatotoxicity markers aspartate aminotransferase (AST) and alanine aminotransferase (ALT) in aWT mice. Therefore, levels of these markers were largely comparable between genotypes with a slight reduction in AST in the female $a K O$ mice (Figure S4J-M). 

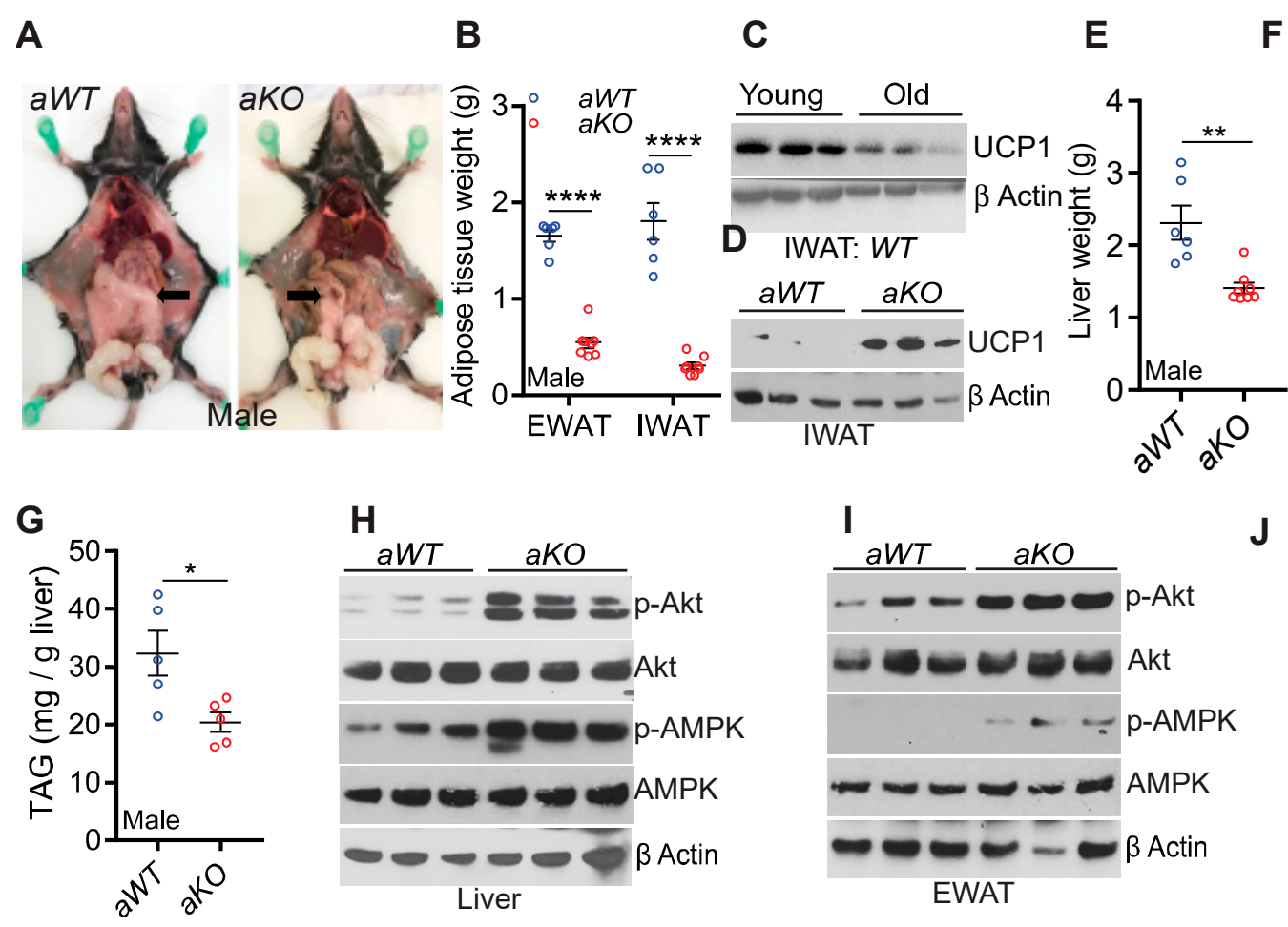

J
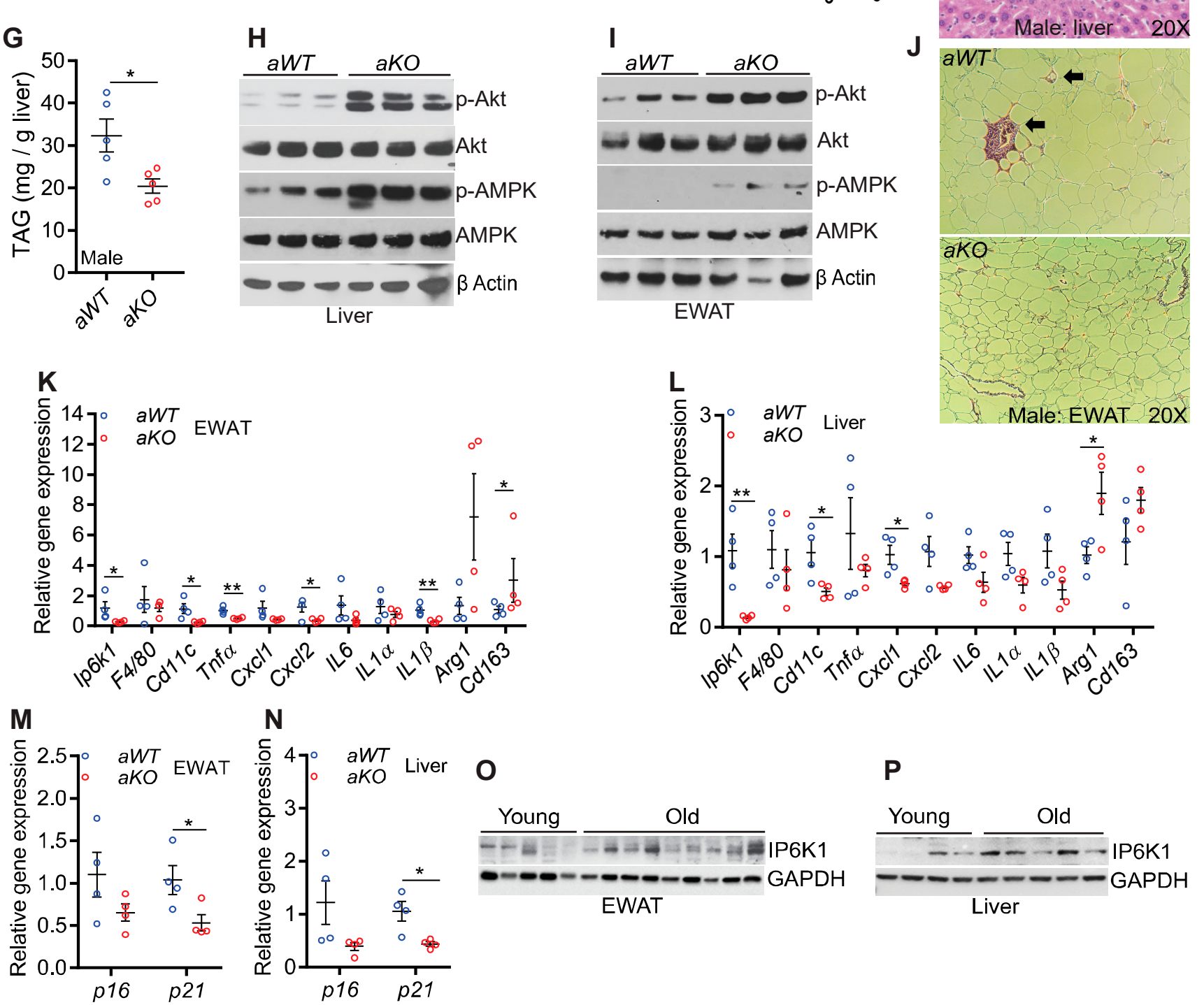

Figure 4. Age-induced metabolic aberration in adipose tissue and liver was ameliorated in Ip6k1 deleted mice. (A) aKO male mice displayed reduced fat accumulation in adipose tissue depots. (B) Weight of epididymal and inguinal (EWAT and IWAT) adipose tissue depots was reduced in male $a K O$ mice. $n=6$, and 8 for $a W T$ and $a K O$ mice. (C) Aging downregulated UCP1 protein in the IWAT of $W T$ mice. (D) UCP1 protein levels were higher in the IWAT of $a K O$, compared to $a W T$ mice. (E) Liver weight was reduced in $a K O$ mice. $n=6$, and 8 for $a W T$ and $a K O$ mice. (F,G) $a K O$ mice exhibited reduced micro-steatosis and TAG accumulation in the liver. $n=5$ mice per group. $(\mathbf{H}, \mathbf{I})$ Stimulatory 
phosphorylation of Akt (S473) and AMPK (T172) increased in the liver and EWAT of aKO mice. (J) Adipocyte size (EWAT) was reduced and crown like structures (indicated by an arrow) were absent in the EWAT of $a K O$ mice. (K) mRNA expression of $C d 11 c, T n f \alpha, I L 1 \beta$ and $C x c l 2$ were reduced and Cd163 increased in the EWAT of $a K O$ mice. IL6, IL1 $\alpha, C x c l 1$ and Arg1 were insignificantly altered. F4/80 expression was similar in $a W T$ and $a K O$ EWAT. Ip $6 \mathrm{k} 1$ expression was determined to confirm the genotypes. $n=4$ mice per group. (L) mRNA expression of $C d 11 c$ and $C x c l 1$ were diminished whereas Arg1 was augmented in the liver of $a K O$ mice. Tnf $\alpha, C x c l 2, I L 6, I L 1 \alpha, I L 1 \beta$ were downregulated and $C d 163$ was upregulated to insignificant levels. F4/80 expression was similar in $a W T$ and $a K O$ liver. $n=4$ mice per group. (M,N) mRNA expression of $p 21$ was significantly reduced in EWAT and liver of $a K O$ compared to $a W T$ controls. $p 16$ was also downregulated in $a K O$ tissues albeit to insignificant levels. $n=4$ mice per group. (O,P) Aging upregulated IP6K1 at the protein level in EWAT and liver tissues of WT mice. $n=4$ and 5 and 5 and 7 per group for EWAT and liver, respectively. Number of mice $(n)$ used in each experiment are presented as individual datapoints. Mean \pm s.e.m. values are shown within dot plots. For 2 independent data sets, two-tailed unpaired Student's $t$-test was used. ${ }^{*} p<0.05,{ }^{* *} p<0.01,{ }^{* * * *} p<0.0001$.

Improved metabolism and reduced inflammation may have delayed senescence in the adipose tissue and liver of $a K O$ mice, as the senescent markers $p 16$ and $p 21$ were downregulated in the knockouts (Figure 4M,N). Finally, we determined whether IP6K1 is an age-inducible protein in adipose tissue and liver. Aging upregulated IP6K1 protein but not its mRNA expression in these tissues (Figure 4O,P and Figure S4N-P).

Although 22-month-old WT mice, used in this study, developed metabolic dysfunction, we did not observe visual aging phenotypes in these mice. Compared to young WT and $K O$ [35], aWT and $a K O$ mice displayed slightly reduced activity levels, although no significant differences between genotypes were observed (Figure S3E,F). Skin texture and hair quantity and quality appeared normal and were similar in both aged genotypes (Figure 1B,F). Neither genotype developed cataract, kyphosis, or tumor. For senescence and survival studies, 28-36-month-old mice are recommended [49]. Therefore, whether improved metabolism in Ip6k1-deleted mice delays senescence and increases lifespan will be tested in 36-month-old mice in future studies.

\section{Discussion}

Age-induced metabolic dysfunction of adipose tissue and liver increases weight and fat gain and insulin resistance $[5,19,20,50,51]$. The current study shows that whole-body deletion of $I p 6 k 1$ protects mice from age-induced weight gain, insulin resistance and metabolic dysfunction by improving metabolic functions of these tissues. Although both male and female $a K O$ mice displayed overall metabolic improvements, the difference in glycemic profiles was more robust in male than female $a K O$ mice compared to their respective $a W T$ controls. This is explainable as male C57BL6 mice attain insulin resistance faster than female mice with age [42].

Adipocyte- or hepatocyte-specific Ip $6 k 1$ deletion has been shown to improve metabolism and insulin sensitivity in high-fat, high-cholesterol or high-fructose diet-fed mice [34,36]. Here, we observed improved serum, adipose tissue and liver metabolic parameters and increased activities of the IP6K1 targets Akt and AMPK in these tissues of aKO mice. IP6K1 also promotes insulin secretion from the pancreatic $\beta$ cells [31,32]. Thus, improved metabolic functions of these tissues contribute to the observed phenotypes in $a K O$ mice. However, IP6K1 is ubiquitously expressed, including in the brain [26,52,53], and therefore the involvement of the hypothalamic-IP6K1 in metabolic regulation cannot be ruled out. Hypothalamic-AMPK enhances food intake [54]. Thus, a slight increase in food intake (when normalized to body weight) in $a K O$ mice could be due to augmented AMPK activity in the hypothalamus.

Despite increased UCP1 expression and AMPK activation, overall energy expenditure was not increased in $a K O$ mice. Although the reason is not entirely clear at this point, substantial reduction in body fat over time may have readjusted the metabolic rate in $a K O$ mice. However, carbohydrate oxidation was higher, which explains reduced synthesis 
and accumulation of fat in the aged knockouts. This result is in line with our previous findings that young, chow-fed Ip6k1-KO mice exhibit higher carbohydrate oxidation, and IP6K1 reduces fatty acid biosynthesis in adipocytes [35]. Prolonged increase or decrease in energy expenditure may have negative effects on healthspan [50]. Efficient carbohydrate use may provide an alternative therapeutic strategy to ameliorate metabolic dysfunction in aging. Other IP6K1-regulated processes may also contribute to age-induced metabolic dysfunction. For example, IP6K1-generated 5-IP7 maintains the cellular polyphosphate levels and pyrophosphorylates protein targets $[55,56]$ that regulate glycolysis, chemotaxis and phagosomal motility of macrophages [57-59]. Moreover, IP6K1, in coordination with another inositol pyrophosphate biosynthetic enzyme, PPIP5K, generates IP8 [60], which has also been shown to regulate energy metabolism [61]. Therefore, the observed metabolic phenotypes in $a K O$ mice may also arise due to a reduction in IP8.

Age-induced upregulation of IP6K1 explains why IP7 levels are higher in cells isolated from older compared to younger mice $[33,62]$. Interestingly, protein but not mRNA levels of IP6K1 increased in aged adipose tissue, indicating involvement of post-translational events in IP6K1's upregulation. IP6K2 is degraded via the ubiquitin-proteasomal system [63]. Future studies will determine whether IP6K1's stability is regulated by similar mechanisms. Moreover, IP6K1 is phosphorylated at serine residues 118 and 121, which regulates its catalytic activity and interaction with metabolic proteins [32,64]. Whether aging induces IP6K1's activity and protein-protein interaction via these mechanisms will be tested.

Among other Ip $6 k$ isoforms, Ip $6 k 2$ is ubiquitously expressed, and its deletion decreases metastasis [65]. Ip6k3 expression is limited to skeletal muscle and heart, and its whole-body deletion improves skeletal muscle metabolism, protecting mice from age-induced fat gain, insulin resistance and mortality [30]. Thus, targeting the IP6K pathway in general may improve healthspan. Encouragingly, pharmacologic inhibition of this pathway has been shown to ameliorate diet-induced obesity, insulin resistance, hepatic steatosis, osteoporosis, chronic kidney disease, ischemia/reperfusion injury, and myocardial infarction in mouse models [66-70]. Efforts are ongoing to develop potent and improved drug-like IP6K inhibitor compounds for clinical trials [71-73]. IP6K1 is relevant in human metabolic diseases as its levels positively correlate with HOMA-IR (Homeostatic Model Assessment for Insulin Resistance) in prediabetic subjects and negatively corelate to insulin sensitivity [74]. Moreover, IP6K1 is upregulated in the liver of NASH, cirrhosis, and hepatocellular carcinoma patients $[36,75]$. Hopefully, inhibiting IP6K1 or the IP6K pathway will delay age-induced metabolic dysfunction in humans.

\section{Materials and Methods}

\subsection{Chemicals and Reagents}

Unless otherwise stated, all the chemicals were purchased from Sigma/EMD Millipore, St. Louis, MO, USA. Antibodies-IP6K1 (HPA040825), UCP1 (U6382), $\beta$-actin (A5316) and GAPDH (G8795)—were from Sigma/EMD Millipore, St. Louis, MO, USA; p-AMPK (2535), AMPK (2793), p-Akt (4060) were from Cell Signaling Technology, Danvers, MA, USA; Total Akt (Sc-81434) were from Santa Cruz Biotechnology, Dallas, TX, USA. The insulin ELISA kit (90080) was from Crystal Chem Inc., Elk Grove Village, IL, USA. ALT, AST, and TAG assay kits were from Teco Diagnostics, Anaheim, CA, USA; insulin assay kit was from Insulin was from Novo Nordisk, Bagsværd, Denmark.

qRT-PCR Primers (Forward and reverse).

\begin{tabular}{cc}
\hline Gene & Sequence \\
\hline \multirow{2}{*}{ Ip6k1 } & F: 5-TGGAAGTGGGGCAGTATGG-3 \\
& R: 5-CGTCGTACCGCATCATGCT-3 \\
\hline \multirow{2}{*}{ F4/80 } & F: 5-GGATATGGAAACTTCAACTGCAA-3 \\
& R: 5-CAAGTGTACAGAAGGAAGCATAAC-3 \\
\hline
\end{tabular}




\begin{tabular}{|c|c|}
\hline CD11c & $\begin{array}{c}\text { F: 5-CAAATAGGTGGCCTCTACAAATG-3 } \\
\text { R: 5-GTAGGACCACAAGCCAACA-3 }\end{array}$ \\
\hline $\mathrm{TNF} \alpha$ & $\begin{array}{c}\text { F: 5-AGACCCTCACACTCAGATCA-3 } \\
\text { R: 5-GAGTAGACAAGGTACAACCCATC-3 }\end{array}$ \\
\hline Cxcl1 & $\begin{array}{l}\text { F: 5-ACCGAAGTCATAGCCACACTC-3 } \\
\text { R: 5-CTCCGTTACTTGGGGACACC-3 }\end{array}$ \\
\hline Cxcl2 & $\begin{array}{c}\text { F: 5-CCCAGACAGAAGTCATAGCCAC-3 } \\
\text { R: 5-TGGTTCTTCCGTTGAGGGAC-3 }\end{array}$ \\
\hline IL6 & $\begin{array}{l}\text { F: 5-TGAGAAAAGAGTTGTGCAATGG-3 } \\
\text { R: 5-GGTACTCCAGAAGACCAGAGG-3 }\end{array}$ \\
\hline IL1 $\alpha$ & $\begin{array}{l}\text { F: 5-AGGGAGTCAACTCATTGGCG-3 } \\
\text { R: 5-TGGCAGAACTGTAGTCTTCGT-3 }\end{array}$ \\
\hline IL1 $\beta$ & $\begin{array}{c}\text { F: 5-TGCCACCTTTTGACAGTGATG-3 } \\
\text { R: 5-TGATGTGCTGCTGCGAGATT-3 }\end{array}$ \\
\hline Arg1 & $\begin{array}{c}\text { F: 5-TTAGAGATTATCGGAGCGCCT-3 } \\
\text { R: 5-GTCTCTCACGTCATACTCTGTTTCT-3 }\end{array}$ \\
\hline Cd163 & $\begin{array}{l}\text { F: 5-ATTCAGCGACTTACAGTTTCCTC-3 } \\
\text { R: 5-ACAAAGATGTCAGTCCATCATCA-3 }\end{array}$ \\
\hline P16 & $\begin{array}{l}\text { F: 5-ATGGGTCGCAGGTTCTTGG-3 } \\
\text { R: 5-TGCCCATCATCATCACCTGG-3 }\end{array}$ \\
\hline P21 & $\begin{array}{l}\text { F: 5-TTGCCAGCAGAATAAAAGGTGCC-3 } \\
\text { R: 5-GACGAAGTCAAAGTTCCACCGT-3 }\end{array}$ \\
\hline Hprt1 & $\begin{array}{c}\text { F: 5-CAAACTTTGCTTTCCCTGGT-3 } \\
\text { R: 5-TCTGGCCTGTATCCAACACTTC-3 }\end{array}$ \\
\hline Rplp0 & $\begin{array}{l}\text { F: 5-AGATTCGGGATATGCTGTTGGC-3 } \\
\text { R: 5-TCGGGTCCTAGACCAGTGTTC-3 }\end{array}$ \\
\hline
\end{tabular}

\subsection{Animals}

Animal care and experiments were approved by the Saint Louis University School of Medicine and The Scripps Research Institute Institutional Animal Care and Use Committee (IACUC). Male WT and Ip6k1-KO (KO) mice on pure C57BL6 background were housed in a $12 \mathrm{~h}$ light $/ 12 \mathrm{~h}$ dark cycles at $23{ }^{\circ} \mathrm{C}$ and were fed a standard chow diet (Harlan Laboratories \# 2018SX). At indicated time periods, body weight and composition, energy expenditure, blood glucose level, GTT and ITT were performed. After 22-months, mice were fasted for $4 \mathrm{~h}$ (to minimize nibbling induced changes in metabolism and signaling) and then euthanized by carbon dioxide asphyxiation. Tissues were processed for downstream applications. To compare mRNA and protein expression in young vs. old mice, 2- and 22-month-old WT mice were used.

\subsection{Body Composition Analyses by Q-NMR}

Fat, lean and fluid masses of mice were measured using the Minispec LF-NMR (Bruker Optics, Ettlingen, Germany) analyzer. Percent body composition was calculated based on the total body weight of mice.

\subsection{Ad Libitum Glucose Level and Glucose and Insulin Tolerance Tests (GTT and ITT)}

Ad libitum glucose, GTT and ITT were performed in 14-, 15- and 16-month-old mice following previously published procedures. For GTT, glucose $(2 \mathrm{~g} / \mathrm{kg} \mathrm{BW}$, i.p.) was injected in 16-h-fasted animals. For ITT, insulin $(0.75 \mathrm{U} / \mathrm{kg}$ BW, i.p. $)$ was injected in $5 \mathrm{~h}$-fasted mice. Blood glucose levels were measured by glucometer by puncturing tail veins of mice before and after the indicated time periods of injection $[33,36,66]$. 


\subsection{Energy Expenditure and Locomotor Activity Studies}

Mice were placed individually in metabolic cages with a precise thermostatic control in a Comprehensive Laboratory Monitoring System (CLAMS; Columbus Instruments, Columbus, OH, USA) and were acclimatized for $36 \mathrm{~h}$. Afterwards, oxygen consumption, $\left(\mathrm{VO}_{2}\right)$, carbon dioxide release $\left(\mathrm{VCO}_{2}\right)$ and spontaneous locomotor activity were measured for $48 \mathrm{~h}$, following standard procedures [66,76]. Respiratory exchange ratio (RER) and energy expenditure (EE) were calculated using the following equations: $\mathrm{RER}=\mathrm{VCO}_{2} / \mathrm{VO}_{2} ; \mathrm{EE}(\mathrm{kcal} / \mathrm{h})=(3.815+1.232 \times \mathrm{RER}) \times \mathrm{VO}_{2}$. Values were normalized by lean body mass. Percent carbohydrate and fat expenditure was calculated following standard procedures $[35,77]$.

\subsection{Food Intake Studies}

Mice were singly housed and acclimatized in this condition for 2 days. On the day of the experiment, the chow diet was weighed and then placed in the cage at 6 p.m. The remaining amount of food was weighed in the following day at the same time to quantify the 24-h food intake. This process was continued for 7 days. The average amount of food consumed per mouse per day was calculated. The mice had full access to drinking water throughout the study.

\subsection{Blood Collection and Assessment of Serum Metabolic Parameters}

Blood was collected from 4-h-fasted mice by cardiac puncture, and serum was prepared following standard procedure. Serum TAG, NEFA, cholesterol and phospholipids were measured at the Mouse Metabolic Phenotyping Centers (MMPC), University of Cincinnati, College of Medicine Pathology \& Laboratory Medicine. Serum insulin concentration was determined by using an ultra-sensitive mouse ELISA kit (Crystal Chem, Elk Grove Village, IL, USA). Serum AST and ALT levels were measured using commercial kits from Teco Diagnostics (Anaheim, CA, USA). Hepatic lipid extraction for TAG measurement was performed following a standard protocol [36].

\subsection{RNA Isolation and $q R T-P C R$ Studies}

RNA isolation and qRT-PCR were conducted following a standard $\Delta \Delta C T$ method [36]. Hypoxanthine guanine phosphoribosyl transferase (Hprt1) and acidic ribosomal protein large P0 (Arp) mRNA were used as controls for adipose tissue and liver, respectively. The comparative threshold cycle method was used to calculate changes in mRNA abundance.

\subsection{Histology}

Adipose tissue and right lobe of the liver tissue were fixed in 10\% neutral buffered formalin for two days. Eight micron-sections were prepared and subsequently stained with hematoxylin and eosin (H\&E) [36,66].

\subsection{Gel Electrophoresis and Immunoblotting}

For immunoblotting, total protein was isolated by standard protein lysis RIPA buffer containing the protease-phosphatase inhibitor tablet and quantified using a BCA protein assay kit (Thermo-Scientific, Waltham, MA, USA). An equal amount of total protein was loaded onto $10 \%$ SDS-PAGE. Proteins were detected by immunoblotting following our standard protocol [66]. Densitometric analyses of protein bands were performed using the ImageJ software (Java 1.8.0_172).

\subsection{Statistics}

For multiple comparisons, two-way Anova with Holm-Sidak multiple comparison test was used. For two independent data sets, two-tailed Student's $t$-test was used. Data are presented as mean $\pm \operatorname{SEM}\left({ }^{* * * *} p<0.0001,{ }^{* * *} p<0.001,{ }^{* *} p<0.01\right.$ and $\left.{ }^{*} p<0.05\right)$. Statistical significance and area under curve (AUC) were calculated in GraphPad Prism software, 
v. 7. Immunoblots were quantified using 'ImageJ' software. Data are plotted for individual animal to show number of animals per experiment.

Supplementary Materials: The following supporting information can be downloaded at: https: //www.mdpi.com/article/10.3390/ijms23042059/s1.

Author Contributions: Conceptualization, A.C. methodology, S.G., S.M. and M.C.; validation, A.C., S.G., S.M. and M.C.; formal analysis, A.C., S.G., S.M., M.C., E.N.M. and J.H.; investigation, A.C., S.G., S.M., M.C., E.N.M. and J.H.; resources, A.C. data curation, A.C., S.G., S.M., M.C., E.N.M. and J.H.; writing-original draft preparation, A.C.; writing-review and editing A.C., S.G. and S.M.; supervision, A.C.; project administration, A.C.; funding acquisition, A.C. All authors have read and agreed to the published version of the manuscript.

Funding: This research was funded by the NIH grant NIDDK-R01DK103746 and the Saint Louis University startup funds to Anutosh Chakraborty.

Institutional Review Board Statement: Animal care and experimentations were approved by the Scripps Research Institute Institutional Animal Care and Use Committee Saint Louis University School of Medicine and (IACUC, protocol numbers: 2739, approval date-30 September 2020 and 2732-approval date-12 August 2021).

Informed Consent Statement: Not applicable.

Data Availability Statement: All data are included in the manuscript figures.

Acknowledgments: We thank the metabolic and histology, and comparative medicine core facilities at Scripps Florida and Saint Louis University (SLU) and the members of the department of Pharmacology and Physiology at SLU for sharing instruments and reagents. We also thank the National Mouse Metabolic Phenotyping Centre (MMPC), University of Cincinnati, College of Medicine, Pathology \& Laboratory Medicine, Cincinnati, Ohio for analyzing the serum metabolic parameters.

Conflicts of Interest: The authors declare that they have no conflict of interest.

\section{References}

1. Kyrou, I.; Randeva, H.S.; Tsigos, C.; Kaltsas, G.; Weickert, M.O. Clinical Problems Caused by Obesity. In Endotext; Feingold, K.R., Anawalt, B., Boyce, A., Chrousos, G., de Herder, W.W., Dhatariya, K., Dungan, K., Grossman, A., Hershman, J.M., Hofland, J., et al., Eds.; MDText.com, Inc.: South Dartmouth, MA, USA, 2000.

2. Chakravarthy, M.V.; Neuschwander-Tetri, B.A. The metabolic basis of nonalcoholic steatohepatitis. Endocrinol. Diabetes Metab. 2020, 3, e00112. [CrossRef]

3. Villareal, D.T.; Apovian, C.M.; Kushner, R.F.; Klein, S. Obesity in older adults: Technical review and position statement of the American Society for Nutrition and NAASO, the Obesity Society. Obes. Res. 2005, 13, 1849-1863. [CrossRef] [PubMed]

4. O'Shaughnessy, I.M.; Kasdorf, G.M.; Hoffmann, R.G.; Kalkhoff, R.K. Does aging intensify the insulin resistance of human obesity? J. Clin. Endocrinol. Metab. 1992, 74, 1075-1081. [CrossRef]

5. Palmer, A.K.; Kirkland, J.L. Aging and adipose tissue: Potential interventions for diabetes and regenerative medicine. Exp. Gerontol. 2016, 86, 97-105. [CrossRef]

6. Goldsworthy, M.E.; Potter, P.K. Modelling age-related metabolic disorders in the mouse. Mamm. Genome Off. J. Int. Mamm. Genome Soc. 2014, 25, 487-496. [CrossRef]

7. Kim, I.H.; Kisseleva, T.; Brenner, D.A. Aging and liver disease. Curr. Opin. Gastroenterol. 2015, 31, 184-191. [CrossRef] [PubMed]

8. Chouchani, E.T.; Kajimura, S. Metabolic adaptation and maladaptation in adipose tissue. Nat. Metab. 2019, 1, 189-200. [CrossRef] [PubMed]

9. Rosen, E.D.; Spiegelman, B.M. What we talk about when we talk about fat. Cell 2014, 156, 20-44. [CrossRef] [PubMed]

10. Kajimura, S.; Spiegelman, B.M.; Seale, P. Brown and Beige Fat: Physiological Roles beyond Heat Generation. Cell Metab. 2015, 22, 546-559. [CrossRef]

11. Tseng, Y.H.; Cypess, A.M.; Kahn, C.R. Cellular bioenergetics as a target for obesity therapy. Nat. Rev. Drug Discov. 2010, 9, 465-482. [CrossRef]

12. Poher, A.L.; Veyrat-Durebex, C.; Altirriba, J.; Montet, X.; Colin, D.J.; Caillon, A.; Lyautey, J.; Rohner-Jeanrenaud, F. Ectopic UCP1 Overexpression in White Adipose Tissue Improves Insulin Sensitivity in Lou/C Rats, a Model of Obesity Resistance. Diabetes 2015, 64, 3700-3712. [CrossRef] [PubMed]

13. Stern, J.H.; Rutkowski, J.M.; Scherer, P.E. Adiponectin, Leptin, and Fatty Acids in the Maintenance of Metabolic Homeostasis through Adipose Tissue Crosstalk. Cell Metab. 2016, 23, 770-784. [CrossRef]

14. Bluher, M. Adipose tissue dysfunction contributes to obesity related metabolic diseases. Best Pract. Res. Clin. Endocrinol. Metab. 2013, 27, 163-177. [CrossRef] 
15. Kahn, C.R.; Wang, G.; Lee, K.Y. Altered adipose tissue and adipocyte function in the pathogenesis of metabolic syndrome. J. Clin. Investig. 2019, 129, 3990-4000. [CrossRef]

16. Brunt, E.M.; Wong, V.W.; Nobili, V.; Day, C.P.; Sookoian, S.; Maher, J.J.; Bugianesi, E.; Sirlin, C.B.; Neuschwander-Tetri, B.A.; Rinella, M.E. Nonalcoholic fatty liver disease. Nat. Rev. Dis. Primers 2015, 1, 15080. [CrossRef] [PubMed]

17. Friedman, S.L.; Neuschwander-Tetri, B.A.; Rinella, M.; Sanyal, A.J. Mechanisms of NAFLD development and therapeutic strategies. Nat. Med. 2018, 24, 908-922. [CrossRef] [PubMed]

18. Rogers, N.H.; Landa, A.; Park, S.; Smith, R.G. Aging leads to a programmed loss of brown adipocytes in murine subcutaneous white adipose tissue. Aging Cell 2012, 11, 1074-1083. [CrossRef]

19. Graja, A.; Gohlke, S.; Schulz, T.J. Aging of Brown and Beige/Brite Adipose Tissue. Handb. Exp. Pharmacol. 2019, $251,55-72$. [CrossRef]

20. Rogers, N.H.; Smith, R.G. Brown-to-white transition in subcutaneous fat: Linking aging and disease. Aging 2012, 4, 728-729. [CrossRef] [PubMed]

21. Gong, Z.; Tas, E.; Yakar, S.; Muzumdar, R. Hepatic lipid metabolism and non-alcoholic fatty liver disease in aging. Mol. Cell. Endocrinol. 2017, 455, 115-130. [CrossRef]

22. Brown, M.S.; Goldstein, J.L. Selective versus total insulin resistance: A pathogenic paradox. Cell Metab. 2008, 7, 95-96. [CrossRef]

23. Pawłowski, K. Uncharacterized/hypothetical proteins in biomedical 'omics' experiments: Is novelty being swept under the carpet? Brief. Funct. Genom. Proteom. 2008, 7, 283-290. [CrossRef]

24. Shears, S.B. Diphosphoinositol polyphosphates: Metabolic messengers? Mol. Pharm. 2009, 76, 236-252. [CrossRef] [PubMed]

25. Saiardi, A. Cell signalling by inositol pyrophosphates. Sub-Cell. Biochem. 2012, 59, 413-443. [CrossRef]

26. Chakraborty, A. The inositol pyrophosphate pathway in health and diseases. Biol. Rev. Camb. Philos. Soc. 2018, 93, 1203-1227. [CrossRef] [PubMed]

27. Shah, A.; Ganguli, S.; Sen, J.; Bhandari, R. Inositol Pyrophosphates: Energetic, Omnipresent and Versatile Signalling Molecules. J. Indian Inst. Sci. 2017, 97, 23-40. [CrossRef] [PubMed]

28. Thomas, M.P.; Potter, B.V. The enzymes of human diphosphoinositol polyphosphate metabolism. FEBS J. 2014, 281, 14-33 [CrossRef]

29. Mukherjee, S.; Haubner, J.; Chakraborty, A. Targeting the Inositol Pyrophosphate Biosynthetic Enzymes in Metabolic Diseases. Molecules 2020, 25, 1403. [CrossRef] [PubMed]

30. Moritoh, Y.; Oka, M.; Yasuhara, Y.; Hozumi, H.; Iwachidow, K.; Fuse, H.; Tozawa, R. Inositol Hexakisphosphate Kinase 3 Regulates Metabolism and Lifespan in Mice. Sci. Rep. 2016, 6, 32072. [CrossRef]

31. Illies, C.; Gromada, J.; Fiume, R.; Leibiger, B.; Yu, J.; Juhl, K.; Yang, S.N.; Barma, D.K.; Falck, J.R.; Saiardi, A.; et al. Requirement of inositol pyrophosphates for full exocytotic capacity in pancreatic beta cells. Science 2007, 318, 1299-1302. [CrossRef]

32. Zhang, X.; Li, N.; Zhang, J.; Zhang, Y.; Yang, X.; Luo, Y.; Zhang, B.; Xu, Z.; Zhu, Z.; Yang, X.; et al. 5-IP(7) is a GPCR messenger mediating neural control of synaptotagmin-dependent insulin exocytosis and glucose homeostasis. Nat. Metab. 2021, 3, 1400-1414. [CrossRef]

33. Chakraborty, A.; Koldobskiy, M.A.; Bello, N.T.; Maxwell, M.; Potter, J.J.; Juluri, K.R.; Maag, D.; Kim, S.; Huang, A.S.; Dailey, M.J.; et al. Inositol pyrophosphates inhibit Akt signaling, thereby regulating insulin sensitivity and weight gain. Cell 2010, 143, 897-910. [CrossRef] [PubMed]

34. Zhu, Q.; Ghoshal, S.; Rodrigues, A.; Gao, S.; Asterian, A.; Kamenecka, T.M.; Barrow, J.C.; Chakraborty, A. Adipocyte-specific deletion of Ip6k1 reduces diet-induced obesity by enhancing AMPK-mediated thermogenesis. J. Clin. Investig. 2016, 126, 4273-4288. [CrossRef] [PubMed]

35. Zhu, Q.; Ghoshal, S.; Tyagi, R.; Chakraborty, A. Global IP6K1 deletion enhances temperature modulated energy expenditure which reduces carbohydrate and fat induced weight gain. Mol. Metab. 2017, 6, 73-85. [CrossRef] [PubMed]

36. Mukherjee, S.; Chakraborty, M.; Ulmasov, B.; McCommis, K.; Zhang, J.; Carpenter, D.; Msengi, E.N.; Haubner, J.; Guo, C.; Pike, D.P.; et al. Pleiotropic actions of IP6K1 mediate hepatic metabolic dysfunction to promote nonalcoholic fatty liver disease and steatohepatitis. Mol. Metab. 2021, 54, 101364. [CrossRef] [PubMed]

37. Bhandari, R.; Juluri, K.R.; Resnick, A.C.; Snyder, S.H. Gene deletion of inositol hexakisphosphate kinase 1 reveals inositol pyrophosphate regulation of insulin secretion, growth, and spermiogenesis. Proc. Natl. Acad. Sci. USA 2008, 105, 2349-2353. [CrossRef] [PubMed]

38. Shansky, R.M. Are hormones a "female problem" for animal research? Science 2019, 364, 825-826. [CrossRef]

39. Clayton, J.A.; Collins, F.S. Policy: NIH to balance sex in cell and animal studies. Nature 2014, 509, 282-283. [CrossRef]

40. Mauvais-Jarvis, F. Sex differences in metabolic homeostasis, diabetes, and obesity. Biol. Sex Differ. 2015, 6, 14. [CrossRef]

41. Halvorson, C.L.; De Bond, J.P.; Maloney, S.K.; Smith, J.T. Thermoneutral conditions correct the obese phenotype in female, but not male, Kiss1r knockout mice. J. Therm. Biol. 2020, 90, 102592. [CrossRef]

42. Reynolds, T.H.; Dalton, A.; Calzini, L.; Tuluca, A.; Hoyte, D.; Ives, S.J. The impact of age and sex on body composition and glucose sensitivity in C57BL/6J mice. Physiol. Rep. 2019, 7, e13995. [CrossRef]

43. Guo, J.; Jou, W.; Gavrilova, O.; Hall, K.D. Persistent diet-induced obesity in male C57BL/6 mice resulting from temporary obesigenic diets. PLoS ONE 2009, 4, e5370. [CrossRef]

44. Olefsky, J.M.; Glass, C.K. Macrophages, inflammation, and insulin resistance. Annu. Rev. Physiol. 2010, 72, 219-246. [CrossRef] 
45. Kuroda, M.; Sakaue, H. Adipocyte Death and Chronic Inflammation in Obesity. J. Med. Investig. JMI 2017, 64, 193-196. [CrossRef] [PubMed]

46. Eguchi, A.; Feldstein, A.E. Adipocyte cell death, fatty liver disease and associated metabolic disorders. Dig. Dis. 2014, 32, 579-585 [CrossRef] [PubMed]

47. Russo, L.; Lumeng, C.N. Properties and functions of adipose tissue macrophages in obesity. Immunology 2018, 155, 407-417. [CrossRef]

48. Rouault, C.; Pellegrinelli, V.; Schilch, R.; Cotillard, A.; Poitou, C.; Tordjman, J.; Sell, H.; Clément, K.; Lacasa, D. Roles of chemokine ligand-2 (CXCL2) and neutrophils in influencing endothelial cell function and inflammation of human adipose tissue. Endocrinology 2013, 154, 1069-1079. [CrossRef] [PubMed]

49. Pettan-Brewer, C.; Treuting, P.M. Practical pathology of aging mice. Pathobiol. Aging Age Relat. Dis. 2011, 1, 7202. [CrossRef]

50. Bartke, A.; Brannan, S.; Hascup, E.; Hascup, K.; Darcy, J. Energy Metabolism and Aging. World J. Men's Health 2021, 39, 222-232. [CrossRef]

51. Thomas, D.D.; Corkey, B.E.; Istfan, N.W.; Apovian, C.M. Hyperinsulinemia: An Early Indicator of Metabolic Dysfunction. J. Endocr. Soc. 2019, 3, 1727-1747. [CrossRef]

52. Chakraborty, A.; Latapy, C.; Xu, J.; Snyder, S.H.; Beaulieu, J.M. Inositol hexakisphosphate kinase-1 regulates behavioral responses via GSK3 signaling pathways. Mol. Psychiatry 2014, 19, 284-293. [CrossRef]

53. Fu, C.; Xu, J.; Cheng, W.; Rojas, T.; Chin, A.C.; Snowman, A.M.; Harraz, M.M.; Snyder, S.H. Neuronal migration is mediated by inositol hexakisphosphate kinase 1 via alpha-actinin and focal adhesion kinase. Proc. Natl. Acad. Sci. USA 2017, 114, 2036-2041. [CrossRef] [PubMed]

54. Hardie, D.G.; Ross, F.A.; Hawley, S.A. AMPK: A nutrient and energy sensor that maintains energy homeostasis. Nat. Rev. Mol. Cell Biol. 2012, 13, 251-262. [CrossRef]

55. Saiardi, A. How inositol pyrophosphates control cellular phosphate homeostasis? Adv. Biol. Regul. 2012, 52, 351-359. [CrossRef]

56. Saiardi, A.; Bhandari, R.; Resnick, A.C.; Snowman, A.M.; Snyder, S.H. Phosphorylation of proteins by inositol pyrophosphates. Science 2004, 306, 2101-2105. [CrossRef] [PubMed]

57. Chanduri, M.; Rai, A.; Malla, A.B.; Wu, M.; Fiedler, D.; Mallik, R.; Bhandari, R. Inositol hexakisphosphate kinase 1 (IP6K1) activity is required for cytoplasmic dynein-driven transport. Biochem. J. 2016, 473, 3031-3047. [CrossRef] [PubMed]

58. Hou, Q.; Liu, F.; Chakraborty, A.; Jia, Y.; Prasad, A.; Yu, H.; Zhao, L.; Ye, K.; Snyder, S.H.; Xu, Y.; et al. Inhibition of IP6K1 suppresses neutrophil-mediated pulmonary damage in bacterial pneumonia. Sci. Transl. Med. 2018, 10, eaal4045. [CrossRef]

59. Szijgyarto, Z.; Garedew, A.; Azevedo, C.; Saiardi, A. Influence of inositol pyrophosphates on cellular energy dynamics. Science 2011, 334, 802-805. [CrossRef] [PubMed]

60. Choi, J.H.; Williams, J.; Cho, J.; Falck, J.R.; Shears, S.B. Purification, sequencing, and molecular identification of a mammalian PP-InsP5 kinase that is activated when cells are exposed to hyperosmotic stress. J. Biol. Chem. 2007, 282, 30763-30775. [CrossRef]

61. Gu, C.; Nguyen, H.-N.; Ganini, D.; Chen, Z.; Jessen, H.J.; Gu, Z.; Wang, H.; Shears, S.B. KO of 5-InsP7 kinase activity transforms the HCT116 colon cancer cell line into a hypermetabolic, growth-inhibited phenotype. Proc. Natl. Acad. Sci. USA 2017, 114, 11968-11973. [CrossRef] [PubMed]

62. Zhang, Z.; Zhao, C.; Liu, B.; Liang, D.; Qin, X.; Li, X.; Zhang, R.; Li, C.; Wang, H.; Sun, D.; et al. Inositol pyrophosphates mediate the effects of aging on bone marrow mesenchymal stem cells by inhibiting Akt signaling. Stem Cell Res. 2014, 5, 33. [CrossRef]

63. Chakraborty, A.; Werner, J.K., Jr.; Koldobskiy, M.A.; Mustafa, A.K.; Juluri, K.R.; Pietropaoli, J.; Snowman, A.M.; Snyder, S.H. Casein kinase-2 mediates cell survival through phosphorylation and degradation of inositol hexakisphosphate kinase-2. Proc. Natl. Acad. Sci. USA 2011, 108, 2205-2209. [CrossRef]

64. Ghoshal, S.; Tyagi, R.; Zhu, Q.; Chakraborty, A. Inositol hexakisphosphate kinase-1 interacts with perilipin1 to modulate lipolysis. Int. J. Biochem. Cell Biol. 2016, 78, 149-155. [CrossRef]

65. Rao, F.; Xu, J.; Fu, C.; Cha, J.Y.; Gadalla, M.M.; Xu, R.; Barrow, J.C.; Snyder, S.H. Inositol pyrophosphates promote tumor growth and metastasis by antagonizing liver kinase B1. Proc. Natl. Acad. Sci. USA 2015, 112, 1773-1778. [CrossRef]

66. Ghoshal, S.; Zhu, Q.; Asteian, A.; Lin, H.; Xu, H.; Ernst, G.; Barrow, J.C.; Xu, B.; Cameron, M.D.; Kamenecka, T.M.; et al. TNP [N2-(m-Trifluorobenzyl), N6-(p-nitrobenzyl)purine] ameliorates diet induced obesity and insulin resistance via inhibition of the IP6K1 pathway. Mol. Metab. 2016, 5, 903-917. [CrossRef] [PubMed]

67. Boregowda, S.V.; Ghoshal, S.; Booker, C.N.; Krishnappa, V.; Chakraborty, A.; Phinney, D.G. IP6K1 Reduces Mesenchymal Stem/Stromal Cell Fitness and Potentiates High Fat Diet-Induced Skeletal Involution. Stem Cells 2017, 35, 1973-1983. [CrossRef] [PubMed]

68. Moritoh, Y.; Abe, S.I.; Akiyama, H.; Kobayashi, A.; Koyama, R.; Hara, R.; Kasai, S.; Watanabe, M. The enzymatic activity of inositol hexakisphosphate kinase controls circulating phosphate in mammals. Nat. Commun. 2021, 12, 4847. [CrossRef] [PubMed]

69. Sun, D.; Li, S.; Wu, H.; Zhang, M.; Zhang, X.; Wei, L.; Qin, X.; Gao, E. Oncostatin M (OSM) protects against cardiac ischaemia/reperfusion injury in diabetic mice by regulating apoptosis, mitochondrial biogenesis and insulin sensitivity. J. Cell. Mol. Med. 2015, 19, 1296-1307. [CrossRef]

70. Zhang, Z.; Liang, D.; Gao, X.; Zhao, C.; Qin, X.; Xu, Y.; Su, T.; Sun, D.; Li, W.; Wang, H.; et al. Selective inhibition of inositol hexakisphosphate kinases (IP6Ks) enhances mesenchymal stem cell engraftment and improves therapeutic efficacy for myocardial infarction. Basic Res. Cardiol. 2014, 109, 417. [CrossRef] 
71. Puhl-Rubio, A.C.; Stashko, M.A.; Wang, H.; Hardy, P.B.; Tyagi, V.; Li, B.; Wang, X.; Kireev, D.; Jessen, H.J.; Frye, S.V.; et al. Use of Protein Kinase-Focused Compound Libraries for the Discovery of New Inositol Phosphate Kinase Inhibitors. SLAS Discov. Adv. Life Sci. R D 2018, 23, 982-988. [CrossRef]

72. Gu, C.; Stashko, M.A.; Puhl-Rubio, A.C.; Chakraborty, M.; Chakraborty, A.; Frye, S.V.; Pearce, K.H.; Wang, X.; Shears, S.B.; Wang, H. Inhibition of Inositol Polyphosphate Kinases by Quercetin and Related Flavonoids: A Structure-Activity Analysis. J. Med. Chem. 2019, 62, 1443-1454. [CrossRef] [PubMed]

73. Liao, G.; Ye, W.; Heitmann, T.; Ernst, G.; DePasquale, M.; Xu, L.; Wormald, M.; Hu, X.; Ferrer, M.; Harmel, R.K.; et al. Identification of Small-Molecule Inhibitors of Human Inositol Hexakisphosphate Kinases by High-Throughput Screening. ACS Pharmacol. Transl. Sci. 2021, 4, 780-789. [CrossRef] [PubMed]

74. Naufahu, J.; Elliott, B.; Markiv, A.; Dunning-Foreman, P.; McGrady, M.; Howard, D.; Watt, P.; Mackenzie, R.W.A. High intensity exercise decreases IP6K1 muscle content \& improves insulin sensitivity (SI2*) in glucose intolerant individuals. J. Clin. Endocrinol. Metab. 2017, 103, 1479-1490. [CrossRef]

75. Nwosu, Z.C.; Megger, D.A.; Hammad, S.; Sitek, B.; Roessler, S.; Ebert, M.P.; Meyer, C.; Dooley, S. Identification of the Consistently Altered Metabolic Targets in Human Hepatocellular Carcinoma. Cell. Mol. Gastroenterol. Hepatol. 2017, 4, 303-323.e301. [CrossRef] [PubMed]

76. Tschop, M.H.; Speakman, J.R.; Arch, J.R.; Auwerx, J.; Bruning, J.C.; Chan, L.; Eckel, R.H.; Farese, R.V., Jr.; Galgani, J.E.; Hambly, C.; et al. A guide to analysis of mouse energy metabolism. Nat. Methods 2012, 9, 57-63. [CrossRef] [PubMed]

77. Lusk, G. Animal calorimetry. Twenty-fourth paper. Analysis of the oxidation of mixtures of carbohydrate and fat. A correction. $J$. Biol. Chem. 1924, 59, 41-42. [CrossRef] 